\title{
Fred i Østasien
}

Af Stein Tønnesson

Når europæiske medier omtaler

Østasien, er det som regel det

faretruende som fremhæves:

Våbenudvikling og krigstrusler i

Korea eller Det sydkinesiske hav,

fare for handelskrig mellem Kina

og USA, konflikt i Taiwanstrædet, undertrykkelse i Kina og Vietnam, politiske mord i Cambodia, drab på narkotikaforhandlere i Filippinerne, terror i Indonesien, kup i Thailand, korruption i Malaysia eller fordrivelse af Rohingyaer fra Myanmar.

Det vi ikke hører så meget om er, at Østasien siden slutningen af 1970'erne har været bemærkelsesværdig fredeligt, uden en eneste krig mellem stater og med færre og mindre intense borgerkrige end tidligere. Freden i Østasien har udgjort en forudsætning for den vækst i almindelig velstand, som er sket i nær sagt hvert eneste af regionens lande, faktisk også Nordkorea.

Hvis den aktuelle krise på Koreahalvøen, med atomsprængninger, raketforsøg, økonomiske sanktioner, amerikanske krigstrusler - og dernæst diplomati på højeste niveau - skulle ende med en fredsaftale, som gør $\square$ Hvordan kan vi forklare at en
verdensregion med over 30 pct.
af menneskeheden lykkedes med
at befri sig fra krigens uvæsen og
blive verdens nye værksted?

formelt slut på Koreakrigen 1950-53, vil det yderligere forstærke Østasiens fredelige udvikling. Modsat kan krig i Korea få ringvirkninger, der rammer hele verden og gør slut på det østasiatiske mirakel.

I 140 år fra Første Opiumkrig 183942 til krigen mellem Kina og Vietnam i 1979 var Østasien præget af et uhyggeligt antal frygtelige krige, massakrer og menneskeskabte katastrofer. Værst var Taiping-krigene i Kina 1850-64 og Japans krig for et 'større Asien' 1937-45.

Siden 1979 har den østasiatiske befolkning kunnet nyde en høj grad af fred og en enestående økonomisk vækst. Hvordan kan vi forklare, at en verdensregion med over 30 pct. af menneskeheden lykkedes med at befri sig fra krigens uvæsen og blive verdens nye værksted?

Et seksårigt forskningsprogram ved Uppsala universitet i årene 2011- 
17 - under min ledelse - søgte at forklare dette fænomen og vurdere om freden kan fortsætte. Min konklusion blev, at den vigtigste drivkraft var en række prioritetsændringer hos lederne for regionens nationer. På forskellige tidspunkter, hvor de oplevede en national krise, bestemte de sig for at prioritere økonomisk vækst. Så snart de havde gjort det, fik de behov for såvel indenrigs- som udenrigspolitisk stabilitet.

Den regionale fred var således en kumulativ effekt af mange nationale prioritetsændringer. I Uppsala-programmet konkurrerede min tese om en 'udviklingsfred' med flere andre forklaringer baseret på magtbalance, gensidig økonomisk afhængighed eller sydøstasiatisk konsensus-kultur (Bjarnegård, E. \& J. Kreutz, eds (2017) Debating the East Asian Peace. Copenhagen: NIAS Press).

\section{Økonomiens primat}

I denne artikel vil jeg koncentrere mig om min egen teori. Den får mig til at spå, at freden fortsætter, så længe de mægtigste stater i regionen (USA inkluderet) fastholder økonomiens primat. Hvis de gør det, vil regionens magthavere tillade fortsat $\varnothing$ konomisk integration på tværs af landegrænser. I så fald vil Østasien forblive en fredelig region uden alvorlige krige, selv uden at regionens stater opfylder de forudsætninger, som har ligget til grund for Europas regionale fred: Overnational politisk integration, fælles demokratiske værdier og respekt for international lov.

$\varnothing$ stasiens fred kan understøttes af den begejstring og trues af den frygt, som skabes af Kinas øgende magt. Kina kan bruge sin magt til at fremme økonomisk integration gennem sit 'Belt and Road Initiative', som sigter mod at binde hele det indoeuropæiske kontinent sammen med moderne infrastruktur.

Alternativt kan Kina bruge sin magt til at realisere sit mål om genforening med Taiwan og om at underlægge sig øer og maritime zoner i Det sydkinesiske hav. Modsætningen mellem Kinas økonomiske og irredentistiske mål udgør et vanskeligt dilemma for Kinas ledere i det 21. århundrede. Deres $ø$ gende magt og ambitioner skaber ængstelse og modtiltag i Japan og USA.

Under præsident Donald Trump er USA tilsyneladende i gang med at udvirke en handelskrig med det hovedformål at reducere Kinas magt, så USA fortsat kan være verdens eneste supermagt. I striden om Nordkoreas atomprogram står mere på spil end blot Korea. Den handler om det økonomiske og sikkerhedspolitiske trekantforhold Kina-USA-Japan. Det er det vigtigste magtforhold i dagens verden. Europa, Rusland og Indien har roller som berørte og bekymrede tilskuere.

\section{Østasien er noget for sig selv}

$\varnothing$-tasien forstås her som en region bestående af Nordøstasien (Kina, Mongoliet, Nordkorea, Sydkorea og Japan) og Sydøstasien (de ti medlemmer af ASEAN - Association of Southeast Asian Nations). Den fred, som nu har præget regionen i tre-fire årtier, står i modsætning til en lang forudgående 
periode med borgerkrige, krige mellem stater i regionen, kolonikrige og verdenskrige. I årene efter 1945 var $\varnothing$ stasien længe den blodigste slagmark i den kolde krig.

Østasiens overgang til fred illustreres gennem Figur 1, som viser estimat for antal krigsdræbte i Østasien samt resten af verden i årene 1946-2015. I perioden 1946-79 stod Østasien for 80 pct. af alle verdens krigsdræbte. I 1980'erne gik procenten ned til 6,2 og lå så lavt som 1,7 i årene 1990-2015. I 2016-17 gik andelen yderligere ned, men desværre var grunden ikke nu nedgang i Østasien, men opgang i Mellemøsten.

Østasiens overgang fra omfattende krigsførelse til relativ fred er vel at mærke et rent østasiatisk fænomen. Det gælder ikke andre dele af Asien. Sydasien, Centralasien og Vestasien (Mellemøsten) var mindre plaget af krig under den kolde krig, men 'overtog' verdens værste krige i 1980'erne.

\section{Begreber og definitioner}

Omkring årtusindskiftet begyndte nogle forskere at interessere sig for $\varnothing$ stasiens fred. Nogle koncentrerede sig om samarbejdet inden for ASEAN andre om det strategiske forhold mellem Kina og USA (Ross, R. S. (2003) 'The U.S.-China Peace: Great Power Politics, Spheres of Influence, and the Peace of East Asia', Journal of East Asian Studies 3(3): 351-376; Solingen, E. (2007) 'Pax Asiatica versus Bella Levantina: The Foundations of War and Peace in East Asia and the Middle East', American Political Science Review 101(4): 757-779.). De førstnævnte forklarede Sydøstasiens fred med en konsensus-kultur, som var blevet skabt mellem ASEAN-landene (Acharya, A.

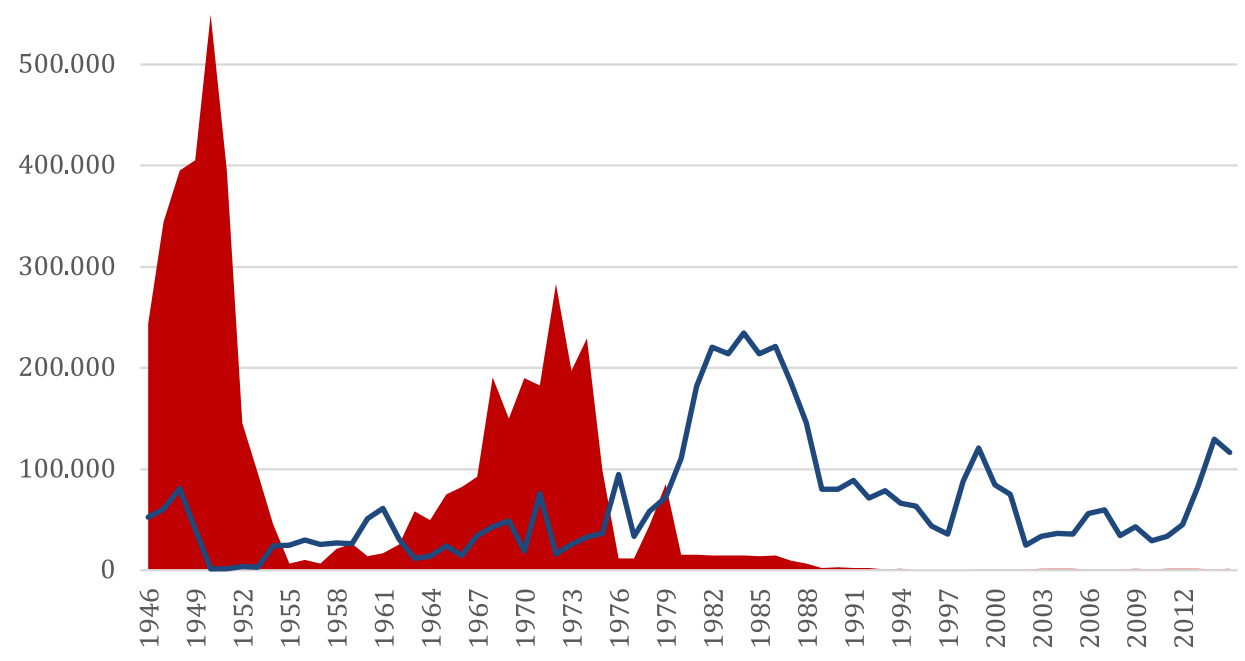

FIGUR 1: Krigsdræbte i Østasien (rød farve) og resten af verden (blå linje), 1946-2015 (PRIO og Uppsala Conflict Data Program (UCDP) battle death data) 
(2001) Constructing a Security Community in Southeast Asia. ASEAN and the Problem of Regional Order. London: Routledge: Kivimäki, T. (2001) 'The Long Peace of ASEAN', Journal of Peace Research 38(1): 5-25), medens de strategisk orienterede forskere lagde vægt på, hvordan magt blev fordelt mellem kontinentalmagten Kina og den maritime stormagt USA.

Begrebet 'Østasien-freden' fik sit gennembrud i fredsforskningen, da et seksårigt forskningsprogram ved

\section{Al vold skal ophøre, og alle grundlæggende menneskelige behov imødekommes, før et samfund kan siges at have nået det fredelige yderpunkt på skalaen.}

Uppsala universitet opnåede finansiering fra det svenske Riksbankens Jubilæumsfond i årene 2011-17. Programmet var inspireret af Timo Kivimäkis pionerarbejde (Kivimäki, T. (2014) The Long Peace of East Asia. London: Ashgate) og en programmatisk artikel af Tønnesson (Tønnesson, S. (2009) 'What Is It that Best Explains the East Asian Peace Since 1979? A Call for a Research Agenda', Asian Perspective 33(1): 111-136).

Programmet sigtede mod at forklare fred på regionalt niveau i stedet for at på traditionel vis analysere krigsudbrud eller krigsafslutninger lokalt, nationalt eller i global statistik.

Programmet løb hurtigt ind i diskussioner om, hvordan fred skal defineres. Begrebet Østasienfreden bygger på en enkel definition af fred som fravær af væbnet konflikt målt i antal krigsdræbte.
Denne smalle definition havde tilladt forskerne i Uppsala at opdage $\varnothing$ stasiens dramatiske overgang til regional fred og at gøre den til studieobjekt. De fleste fredsforskere kan imidlertid ikke acceptere en så begrænset definition af fred. Hvis fravær af væbnet konflikt skyldes militær afskrækkelse eksternt og effektiv undertrykkelse internt, eller hvis andre former for vold end væbnet konflikt er omsiggribende (mord, drab på spædbørn, vold mod kvinder) forekommer det umuligt at betragte et samfund som fredeligt.

Mange fredsforskere ser fred og krig som to yderpunkter på en skala, hvor fravær af krig kun udgør et skridt på vej fra krig mod fred. Al vold skal ophøre, og alle grundlæggende menneskelige behov imødekommes, før et samfund kan siges at have nået det fredelige yderpunkt på skalaen.

Visse fredsforskere er begyndt at tale om fred af lav og høj kvalitet (Melander, E. (2018) 'A Procedural Approach to Quality Peace.' In C. Davenport, E. Melander and P. Regan, The Peace Continuum. Oxford: Oxford University Press: 113-144). Det giver god mening, fordi det anerkender fravær af væbnet konflikt som fred (om end af lav kvalitet) og samtidigt åbner for undersøgelser af, hvordan fredens kvalitet kan forhøjes lokalt, nationalt og regionalt.

\section{Vendepunktet - 1979 eller 1989?}

Østasien-fredens begyndelse kan enten tidsfæstes til 1979 eller 1989. 
Siden 1979, hvor der var krig mellem Kina og Vietnam, har der ikke forekommet en eneste mellemstatslig krig i Østasien og heller ikke nogen borgerkrig med flere tusind dræbte. I februar-marts 1979 gik titusinder af menneskeliv tabt i krigen mellem Kina og Vietnam, og de fortsatte med artilleribeskydning og grænsetræfninger frem til 1987.

Fra 1978 til 1989 pågik samtidigt en lavintensitets-krig i Cambodia (Tredje Indokinakrig) mellem en regering indsat af Vietnam og understøttet af vietnamesiske tropper og en koalition af tre politiske partier, som blev understøttet af Kina, Thailand og USA. Koalitionen domineredes af de Røde Khmer, som i årene før havde gjort sig skyldige i folkemord. I marts 1988 udkæmpede Kina og Vietnam et mindre søslag om et undervandsskær i Det sydkinesiske hav.

Det fortjener at nævnes, for siden da har den kinesiske folkehær overhovedet ikke været i kamp med et andet lands væbnede styrker. I 1989 trak Vietnam sig ud af Cambodia, så en fredsaftale om det hærgede land kunne indgås i Paris 1991. Parisaftalen gjorde slut på den cyklus af Indokina-krige som havde skabt så meget nød og fattigdom i Laos, Cambodia og Vietnam siden 1945.

Fra en kinesisk synsvinkel er det alligevel rimeligt at placere vendepunktet fra krig til fred allerede i 1979 . Folkerepublikken blev medlem af FN i 1971. USA's præsident Richard Nixon besøgte Kina i 1972. En tid efter Mao Zedongs død i 1975 afsluttede Kina hans kulturrevolution, som havde ført til store tab af menneskeliv siden 1966 og forhindret økonomisk udvikling. I 1978 kom den pragmatiske Deng Xiaoping til magten. Kina og USA etablerede diplomatiske forbindelser den 1. januar 1979.

Samme år oversteg værdien af handelen over Stillehavet for første gang handelen over Atlanterhavet. En ny æra med handel, investeringer og teknologioverførsel mellem Kina, Japan og USA blev etableret, i god tid før kommunistregimerne faldt i Østeuropa, Sovjetunionen gik i opløsning, og Vietnam, Laos og Cambodia fik del i den østasiatiske kapitalismes velsignelser.

Først ønskede imidlertid Deng Xiaoping at give Vietnam en lærestreg. Det var baggrunden for invasionen i 1979 og for det militære pres, som Kina opretholdt mod Vietnam helt til 1989. Konflikten mellem Kina og Vietnam forhindrede Vietnam og de kinesiske grænseprovinser Yunnan og Guangxi i at fă del i den fredelige udvikling, som prægede andre dele af Kina og Østasien i 1980'erne.

\section{Udviklingsfred}

Hvordan kan Østasiens overgang til fred forklares? Mit bud er en teori om udviklingsfred (Tønnesson, S. (2017) Explaining the East Asian Peace. Copenhagen: NIAS Press og Tønnesson, S. (2017) 'Peace by Development.' In E. Bjarnegård \& J. Kreutz (eds) Debating the East Asian Peace. Copenhagen: NIAS Press: 55-77). Bedre end at udpege et regionalt vendepunkt er det at fastslå, hvornår de enkelte landes politiske magthavere gik over til at give 
højeste prioritet til $ø$ konomisk vækst.

Japan var pioner i 1945-46 under amerikansk okkupation. En aldrende pro-britisk diplomat, Shigeru Yoshida, tog over som statsminister under amerikansk overopsyn og forblev ved magten det meste af tiden frem til 1954. I 1945-46 var Japan i en ulykkelig stand med byer i ruiner, svigtende madforsyning og en befolkning præget af nød og skam. Dette til trods var der ingen hævnaktioner mod okkupanterne.

Japanerne bestemte sig for at 'omfavne' sit nederlag. Efter amerikansk diktat blev der vedtaget en ny forfatning i 1946, som forbød Japan (i paragraf 9) at føre krig eller have en hær. Den japanske regering koncentrerede sig så om at gennemføre radikale økonomiske reformer med omfordeling af jord og etablering af et Ministerium for International Handel og Industri (MITI), som skulle koordinere den $ø$ konomiske genopbygning.

I 1952, efter at have undertegnet en alliance-aftale med USA, fik Japan sin suverænitet tilbage, undertegnede derefter en fredsaftale i San Francisco med de fleste af sine tidligere fjender og tillod USA at holde baser på japansk jord. I mellemtiden havde USA interveneret i Korea for at redde Sydkorea fra nordkoreansk invasion og senere i Vietnam for at redde Sydvietnam fra et oprør støttet af Nordvietnam. Da USA bad Japan om at tage del i Koreakrigen, sagde Japan nej under henvisning til forfatningen, men tilbød at forsyne USA med det,

de måtte behøve til krigsførelsen mod betaling. Amerikansk efterspørgsel gav således et betydeligt tilskud til Japans økonomiske fremvækst.

Internt i Japan indførte Yoshidas regering et system med effektiv overvågning af al venstreorienteret opposition, så risikoen for politisk uro blev drastisk reduceret. En af den konservative Yoshidas grunde for at stille sig positiv til paragraf $9 \mathrm{i}$ forfatningen var, at den forhindrede arbejderklassen $\mathrm{i}$ at få oplæring i våbenbrug. Yoshidas pragmatiske udenrigspolitik kom senere til at blive kendt som 'Yoshidadoktrinen'. Den var kontroversiel, men tillod japanerne i løbet af kun et par årtier at blive en af verdens rigeste nationer. Det var først i 1990'erne at $\varnothing$ konomien begyndte at stagnere.

Yoshidas japanske udviklingsmodel udgjorde en årsagskæde med følgende led:

\section{NATIONAL KRISE}

nyt lederskab

I prioritering af økonomisk udvikling gennem statslige incitamenter

I behov for ekstern og intern stabilitet $\checkmark$ gode forbindelser med USA som verdens førende magt

I undgåelse af konflikt med nabostater

I undertrykkelse og/eller kooptering af intern opposition

$\checkmark$ amerikanske investeringer, markedstilgang og militær beskyttelse 】 HURTIG ØKONOMISK VÆKST 
Udviklingsfredsteorien er ikke ment at være deterministisk. Den postulerer ikke nogen nødvendig sammenhæng mellem de enkelte led i kæden. Hvert led kan fraviges, hvis andre hensyn end økonomisk vækst får forrang, men hvis det overordnede mål er økonomisk udvikling, indgår hvert led i en logisk sammenhæng.

\section{Læring}

Så snart Japan havde demonstreret sin succes, fulgte andre nationer efter. Det føjede et nyt led til kæden: Læring fra Japan.

- Sydkorea normaliserede sine forbindelser med Japan i 1965. Landet var dybt inspireret af det japanske eksempel og opnåede en eventyrlig $ø$ konomisk succes.

- Da Singapore blev smidt ud af Malaysia i 1965, lykkedes det den lille $\varnothing$ stat inspireret af Japan at blive et velorganiseret knudepunkt for handel og industri.

- Taiwan opgav i 1970'erne målet om at generobre Kina og satsede, med inspiration fra Japan, på økonomisk udvikling. Det lykkedes så godt, at Taiwan senere kunne investere i og inspirere Fastlandskinas udvikling.

- I midten af 1960'erne opgav Indonesien sin konfrontationspolitik mod Malaysia og bad Japan og USA om lån og investeringer. Under general Suhartos brutale 'nye orden' oplevede indoneserne en betydelig velstandsudvikling, som fortsatte efter Suhartos fald i 1998.

- Efter at et kommunistisk oprør i Malaya var blevet nedkæmpet, og føderationen Malaysia var blevet skabt i 1963-65, forsøgte landet sig med en Ny Økonomisk Politik (NEP), hvor det vigtigste mål var at skabe balance mellem landets etniske grupper. Først da statsminister Mahathir Mohamad indførte Look East-politikken fra 1981, blev økonomisk vækst det overordnede mål, og Malaysia kom for alvor med i $\varnothing$ øtasiens velstandsudvikling.

- Allervigtigst: Under Deng Xiaopings pragmatiske lederskab blev markedskræfterne for alvor sluppet løs i Kina. Han efterlignede Japan og fik tilgang til japansk teknologi og investeringer, samarbejdede med USA både økonomisk og sikkerhedspolitisk og lagde grundlaget for, at Kina kunne få en revolutionerende betydning for verdensøkonomien.

- I 1986 kom også Vietnam med i udviklingen med en reformpolitik under slagordet 'Doi Moi'. Vietnam har sidenhen udviklet en diversificeret økonomi med en udenrigspolitik, som sigter mod venskab med alle, dog mest med Kina og USA.

- Det kan diskuteres om Laos og Cambodia hører med blandt udviklingsstaterne. Laos er kommet med i regionens udvikling gennem handel med og investeringer fra nabolandene Kina, Vietnam og Thailand. Cambodias økonomi er præget af korruption og vanstyre, men cambodjanerne har oplevet en endnu stærkere levestandsforbedring end andre af regionens lande, fordi de befandt sig så dybt nede i 1980'erne under den ti år lange oprørskrig mod Vietnams okkupation. Den af Vietnam indsatte statsleder Hun 
Sen, som fortsat sidder ved magten, er blevet en af Kina stærkeste støtter i regionen. Cambodianernes forventede levealder ved fødsel steg fra 33 år i 1981 til 68 år i 2013.

$\varnothing$ stasiens fred var en kumulativ effekt af alle disse nationers satsning på økonomisk vækst, med Japan som pioner og model.

\section{Undtagelserne}

Fire af regionens lande må foreløbig karakteriseres som undtagelser. Thailand har godt nok haft betydelig økonomisk vækst, men ingen af Thailands ledere har lykkedes med at skabe en stabilt organiseret udviklingsstat. Det skyldes et reaktionært monarki, og at civile regeringer aldrig har haft kontrol med de væbnede styrker, som gentagne gange har grebet magten $\mathrm{i}$ kup. Dette gælder i endnu stærkere grad Myanmar, som var et militærdiktatur fra 1962-2011, og hvor den nuværende demokratisk valgte regering er konstitutionelt forhindret $\mathrm{i}$ at kontrollere landets væbnede styrker.

Filippinerne, med dets over 100 millioner indbyggere, bør også regnes til undtagelserne. Alle forsøg på at udvikle en effektiv udviklingsstat er mislykkedes. Ligesom i Thailand har der været betydelig økonomisk vækst, men de store landejendomme og industriforetagener kontrolleres af et lille antal rige familier, som har deres egne prioriteringer.

I de sidste år er Filippinerne desuden svinget fra en pro-amerikansk til en pro-kinesisk udenrigspolitik. Det er ingen tilfældighed, at Thailand,
Myanmar og Filippinerne siden 2005 har været de eneste lande i Østasien, som har pågående interne væbnede konflikter.

Den største undtagelse i regionen er Nordkorea, som aldrig har vovet at satse på international økonomisk integration. Hvis Kim Jong-un lykkes med at realisere sin 'byungjin'-politik, som prioriterer økonomisk udvikling ligeså højt som militær styrke, og gennem fredsforhandlinger og aftaler vover at åbne vej- og jernbaneforbindelser mellem de højt udviklede økonomier i Sydkorea og Kina, så vil det yderligere skærpe billedet af en østasiatisk udviklingsfred.

\section{Foruroligende realisme}

Jeg har lagt vægten på min egen udviklingsfredsteori. Jeg erkender imidlertid at andre tilgange har relevans (Bjarnegård \& Kreutz op. cit.). Den regionale fred ville næppe være kommet i stand uden den strategiske tilnærmelse, der skete mellem Kina og USA i 1970'erne, og som skyldtes deres fælles frygt for Sovjetunionen. I ly af et strategisk samarbejde skabtes en $ø$ konomisk samhandel, som fortsatte efter Sovjetunionens sammenbrud og som først nu for alvor er truet efter som USA stadig mere frygter Kinas voksende magt.

Muligvis er den grundlæggende sikkerhedspolitiske forudsætning for Østasiens udviklingsfred ikke længere til stede. Denne foruroligende mulighed forstærkes af en udbredt holdning blandt kinesiske eksperter på internationale relationer, som formentlig er repræsentativ også for mange beslut- 


\section{Den regionale fred ville næppe være kommet i stand uden den strategiske tilnærmelse, der skete mellem Kina og USA i 1970'erne, og som skyldtes deres fælles frygt for Sovjetunionen.}

di, men drømmer om at gøre gengæld for de ydmygelser, som Kina blev påført af Japan i 1895-1945, udgør alliningstagere inden for Kinas Kommunistiske Parti.

Kinesisk udenrigspolitisk tænkning er ikke meget præget af ægte tro på den officielle doktrin om 'fredelig udvikling'. Realistisk magttænkning har en stærk position i Kina. Fremstående kinesiske eksperter ser risikoen for en amerikansk intervention som den eneste grund til, at Kina afholder sig fra at bruge magt i Taiwanstrædet og i striden om øer i Det Østkinesiske og Sydkinesiske Hav.

Hvis kineserne ikke ser 'fredelig udvikling' som en overordnet værancen mellem USA og Japan en afg $\varnothing$ rende stabilitets- og fredsfaktor. Den kan fortsat tvinge Kina til at afholde sig fra militære eventyr.

Hvis det kun er den amerikanske tilstedeværelse, som får Kina og Japan til at afholde sig fra magtbrug mod hinanden, er det vigtigt for Østasiens fred, at USA opretholder sit militære nærvær, indtil de to østasiatiske stormagter finder ud af det med hinanden - ikke kun økonomisk, men også kulturelt og politisk. 